\title{
THE NESTING HABITS OF THE PULP-MAKING BEE, ALCIDAMEA PRODUCTA CRESS $\mathrm{S}^{\mathrm{I}}$.
}

By Phil Rau,

Kirkwood, Missouri.

It really seems sometimes that the various types of twigdwellers and mud-dwellers among bees and wasps vie with one another to see which can produce a new or novel type of architecture, for certainly they have utilized almost as many different forms and materials in accomplishing their one supremely important task, i.e. providing shelters for their broods, as man has done in precisely the same task. Man has, up to the present time, constructed his domiciles chiefly of caves or excavations, structures of mud, modifications of mud and clay, cement, stone, wood, thatch and, to some extent, paper. So far in our studies of the architecture of our smaller fellowcreatures, we have accounts of their using natural crevices or caverns, excavations, various structures of mud, wax, thatch (grass-carrier), wood (pith-borers and carpenters), and to a large extent paper, and we may add to that list modifications of clay. A. producta, in nesting in hollow stems, uses vegetable matter in a very unusual way; she chews green leaves into soft pulp, and while this is still wet she fashions it into plugs and partitions that make cells for the young.

Grænicher, who has made observations on this bee says, "From Davidson's descriptions of the nest, we learn that the Californian Alcidamea producta builds its nests in the stems of the elder tree by excavating the broken twigs and constructing of pith and clay the partitions between the cells, as also those near the opening of the nest (the 'outer defense,' as Davidson calls them). In our region this bee makes the partitions out of pieces of chewed leaves, and never uses clay for this purpose. In this variation of habits, Alcidamea producta remains true to the habits in vogue within the family to which it belongs, since

Indentified by T. D. A. Cockerell. 
some species of Osmia utilize clay, while others resort to vegetable matter. On July 20, 1903, I witnessed ${ }^{* *}$ a female Alcidamea producta obtaining her leaf material from a wild strawberry $* * *$ the leaves of this plant are rather hairy on the under side, and when thoroughly chewed they form a felt-like, pliable mass."

My St. Louis specimens also failed to behave in just the same way as Davidson's in California; this species, unlike other twig-dwelling bees heretofore reported, makes plugs and partitions of a tough, tightly compressed, green substance which under the microscope proves to be vegetable fibres, $i$. e., portions of leaves chewed to a fibrous pulp and moistened with saliva, which makes wonderfully strong plugs. This material is packed down in layers to form the plug, so that each mouthful forms a distinct stratum (see four layers at (a) in fig. 1). This is tough and well-nigh impenetrable when dry; hence the new adults emerging from beneath this roof cannot bite through, and have adopted an unusual and ingenious method of effecting their escape.

A general description of the nest, and the details of a few typical courses of action will impart a better idea of this bee's ways. These bees nidify in tunnels of elder, sumac or rose stems. Whether they excavate their own burrows or utilize some old ones left by other twig-dwellers, I cannot say. No evidence has been found of previous occupancy of the galleries; in one or two cases we noticed that the nest rested on the very bottom of the cavity, and in as many others the gallery seemed much longer than this bee had any need of, so the meagre evidence is equally divided on this point. The silky cocoons are transparent to a degree that gives one a fairly good view of the organism within.

There is much irregularity in the dimensions of the cells and the partitions. A typical series of measurements is as follows-length of cells in inches: $1,5 / 16,5 / 16,1 / 8,7 / 8,3 / 8$; thickness of partitions: $1 / 8,1 / 8,1 / 16,1 / 4,1 / 4,1 / 8$; air-space 1 $1 / 2$; outer plug: $5 / 8$. In fig. 1 is shown a nest of this species, natural size, in the twig of elder; at " $a$ " one sees the tight plug on the top of the nest, already referred to, and 4 cells are to be seen below "p", which are the partitions made of the fibrous vegetable material. 
The two really unique features of the nests of this species are the material constituting these parts, as described above, and the young bees' way of getting past these plugs which when dried are almost as impenetrable as cement.

Like many other species, these bees arrive at the final stages of their development and emerge successively from the topmost

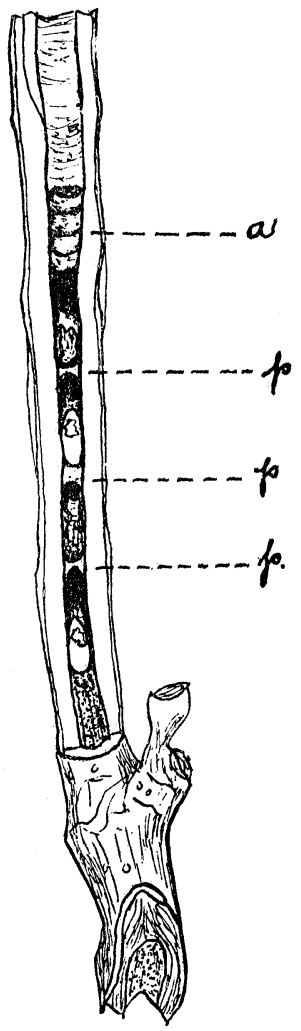

Fig. 1-Nest of Alcidamea producta. Natural size.

down, or in the reverse order of primogeniture. This sequence is apparent at the latter part of the pupal period from the pigmentation of the eyes. The organisms pupate with the head toward the exit.

A typical case in the details of behavior at the time of 
emergence was that in a nest found in a sumac twig in December, 1918. The stalk contained a hollow six inches in depth, at the very bottom of which were four cells, close together. The top was hollow for three inches, except that the orifice was plugged for an inch with chewed-up vegetable material. The twig was kept indoors, and on March 13 two adults emerged. These were the two nearest to the top. Quite unintentionally I aided these two in escaping from their cells, by splitting open the stem for inspection; they emerged by merely biting their way through the side of their cocoons, and escaped. Fully developed young adults could be seen through the transparent walls of the other two cocoons. Mica was sealed over the missing wall to the very top of the stem to compel these remaining bees to attempt to get out by crawling upward by their natural route.

On March 26th I found that the third consecutive bee had emerged from its cocoon. Early next morning it was busy biting its way upward; it entirely demolished the empty cocoon of no. 2 in its upward course and kicked the fragments back in a heap at the bottom. It then had its head against the partitioning plug, where it faced a harder task at breaking through. The next morning, the beginning of the third day, this bee, while apparently in the same position, was industriously attacking this roof, the one which the elder sister, no. 2, should normally have cleared away for it. Its own cell was clean; all debris had been kicked to the bottom. It was attacking not only the roof or partition, but also the surrounding pith against which it was built; it had already bitten out enough of the pith on the sides to enlarge the original cell considerably. It must be remembered that no. 3 was doing additional work. Had nos. 1 and 2 emerged normally, each biting the roof out of its own cell, she would not have had this additional work to do, since each bee has only to break through the roof of its own cell to reach liberty. Unlike certain wasps, e. g. Trypoxylon politum, which can instinctively remove but one covering, and, even if they have the ability to go through a second wall, would rather die than make the attempt, this bee had already shown that she could suit her action to the needs, and not do so by mere instinct, 
either, for already she had made attempts to get out by biting away the pith at the side.

As I watched her more closely at this part of her task I discovered that all of her biting and tugging was not for the one purpose of shredding the fibrous plug, but of moving it whole; even as I watched her she was, with jerk after jerk, working it slowly downward to a point where she had removed pith to loosen its pressure against the walls. I watched intently, doubtful of her success; but she knew her business better than I, and after an arduous session, a bite here and there and a jerk this way and that, she eventually succeeded in turning it up edgewise and pulling it downward as she crept past it, in a depression in the pith at the side; then she kicked it down among the other debris at the bottom. Thus my pretty theory, that she was digging in the pith at the sides to escape by going around the plug, like Prosopis modestus ${ }^{2}$, was left in uncertainty, since now she had moved the whole plug bodily below, only cutting out enough extra space to permit the passing of her own body.

Thus the roof of her cell was disposed of. I should have made clear earlier that each partition comprises two parts or layers, each made of a separate mouthful of fibre; these discs, each about $1 / 8$ inch thick, are near together but separate, one forming the roof of one cell and the other the floor of the cell above. Now that this bee had removed the roof of cell No. 2, she did not stop but went right on attempting to remove bodily the floor of No. 1 also, when a most interesting thing happened. She went to the left wall and bit out a small amount of pith adjacent to the disc, thereby enlarging the channel by perhaps $1 / 8$ inch, again she attempted to remove the plug, but still it did not yield; so she went to the opposite wall and nibbled there a little also, and again tried to jerk the obstruction loose. Thus she continued for a half-hour, directing her blows upon the plug and her bites principally upon the left wall, and occasionally a few nibbles on the right wall; all the time the rasping noise made by her mandibles was distinctly audible. I was called away for a few minutes, and meanwhile the wonderful thing

${ }^{2}$ To be published later. 
happened; when I again looked, she had bitten away so much pith at the left side, in her apparent attempt to loosen the unyielding plug, that she had opened a passageway around the side of it, through which she had escaped. This had led her directly into the bottom end of the empty cocoon above her and she accepted this as a passageway quite unhesitatingly. The channel had originally been only $1 / 8$ inch in diameter, but she had dug out the pith at one side until at that point it was more than 1/4 inch. After this unusual exertion she relaxed for a few minutes of rest; she certainly looked very much at home as she lay there in the cocoon which fitted her perfectly-a replica of the one she had so recently left.

Eternal vigilance is the price of scientific data; had I not returned at that moment $I$ should never have known her method. I expected that next she would go right on through the roof, but for twenty minutes she carefully cleaned out this cell, and with some difficulty pulled away the last bits of cocoon that adhered to the walls. There was no apparent need for this, except as a preliminary to attacking the wall to loosen the top plug. The old plug bottom that she had just passed still adhered to the walls and while her body now pushed it downward she made no further attempt to remove it; it was no longer in her way, so she went on directing her energy to the top plug and the pith on the left side near it. Her process of alternately biting and scratching out the pith, and belaboring the plug, was repeated, accompanied by the same rasping noises and occasionally the falling of bits loosened from the plug, showing that her efforts were not entirely for naught. Of course all this was making it easy for the fourth and last to emerge. Since No. 3 was doing the pioneer work that normally would fall to no. 1 and no. 2, and was succeeding manfully, it again brings to our attention the point that the first-born is not especially endowed with the ability to do worthy work, but it is all a matter of native intelligence, perseverance and strength. If this biting the way out is instinctive-chain instinct if you please-I wonder what happens to those which have no opportunity to use it,- those which merely follow the pioneers and have egress 
with almost no labor. Is it possible that it is not dependent upon instinct, but in the emergency each brings to the fore all its intelligence and resources to cope with the situation, and that those which do not, die?

At the last observation at 7 p. m., I found no. 3 'way up in the top of the channel, having in my absence successfully passed the hard plug by biting her way around it through the soft pith. This compartment was an empty gallery of $33 / 4$ inches, and she had evidently lost no time in traversing the long open stretch. She was already at the very top, attacking the final plug at the orifice. This was the "outer defence," $1 / 4$ inch thick and tightly packed, and I was sorry, for I knew she would have a distressing time with it.

At this time, 7 p. m., no. 4 was barely out of its cocoon, at noon it had been just half-way out; this shows that its progress was slow. Its movements showed, however, that it was struggling hard to make headway through the $3 / 4$ inch of debris that its predecessor had caused to fall down upon it. It reminded me of a cyclone victim trying to free himself from below a pile of broken rubbish. By 8 o'clock the next morning, this one had succeeded in escaping from the debris and was up at the top, complacently waiting beside no. 3 , while the latter was at work cutting her way through the last obstruction. Doubtless no. 4 worked during the night, yet I could not quite overlook the way in which she sat by without disturbing herself in the least, waiting as a matter of course for the older sister to break the way for her. Whenever I noticed them during the forenoon the division of labor continued the same; no. 3 bravely struggled with the plug, often dropping tiny bits of it below, and digging out the pith bit by bit at the left side, while no. 4 quietly waited for her to finish her job.

When I returned at $11 \mathrm{p} . \mathrm{m}$. and examined the nest, I found that no. 3 was out of the nest, and on the floor of the jar-dead. With her jaws she had torn to bits the formidable final plug and thereby acquired her liberty, but with it had come exhaustion and death. In this case futile attempts had been made to bite away the pith beside the plug, although at the point where 
the plug was inserted it was sufficiently thick to make room for a passageway. No. 4 was also dead, in the same place where she was that morning. Whether exhaustion, delay or weakness caused her death I do not know.

One wonders if we may not have a case of the transitional or developmental state of a habit. Most bees in nests having real partitions, attack and perforate the partition itself; Prosopis modestus, we find escapes by cutting a new channel through the pith around the hard partition. The habit of this species of Alcidamea seems to be a reversion to a former habit, i. e., an attack upon the plug, modified by a new trick of removing bits of pith adjacent to the plug in order to loosen it, and this side cutting varying in amount from the removal of a few bits to the tearing out of enough of the pith in one place before the plug is dislodged to permit the passage of the insect's body, and in some cases the biting out of the pith at the sides without any evidence of attack upon the plug itself. One wonders whether Prosopis went through these stages of the arduous struggle with the hard discs before eventually adopting the easier method of detouring through the soft pith, and, if so, how long the species continued its struggle and suffering before is learned its lesson well.

Either the difficulty of the exit or the change of method or some such factor was costing the species a heavy toll of lives at emerging time. More than half of those I watched died before escaping from their secure imprisonment, or died of exhaustion immediately after gaining their liberty. Is this because of the difficulty of their situation, or must hardship or death always be the price of change?

Among the parasites which were found infesting the nests of these bees were Stelis lateralis Cress., [J. C. Crawford], Epistenia osmice [S. A. Rohwer] and Stelis sexmaculata Ash., [J. C. Crawford]. My twigs were gathered too late in the season to study the relation between parasites and host. A very important paper has been written by Dr. S. Grænicher ${ }^{3}$ who was fortunate in finding nests with both parasite and host larvæ in the cells.

${ }^{3}$ Bull. Wisc. Nat. Hist. Soc. 3; 153-167, 1905. 

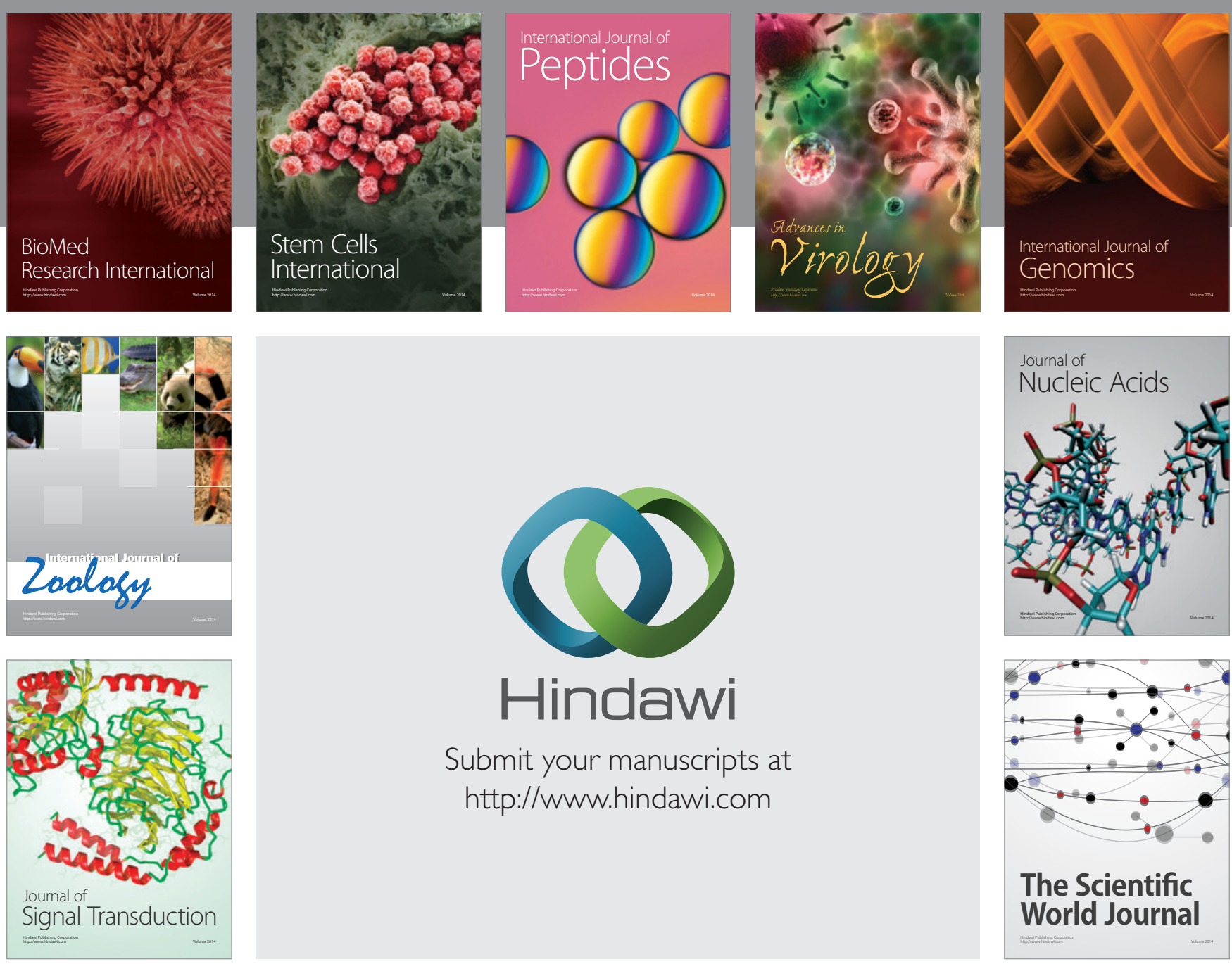

Submit your manuscripts at

http://www.hindawi.com
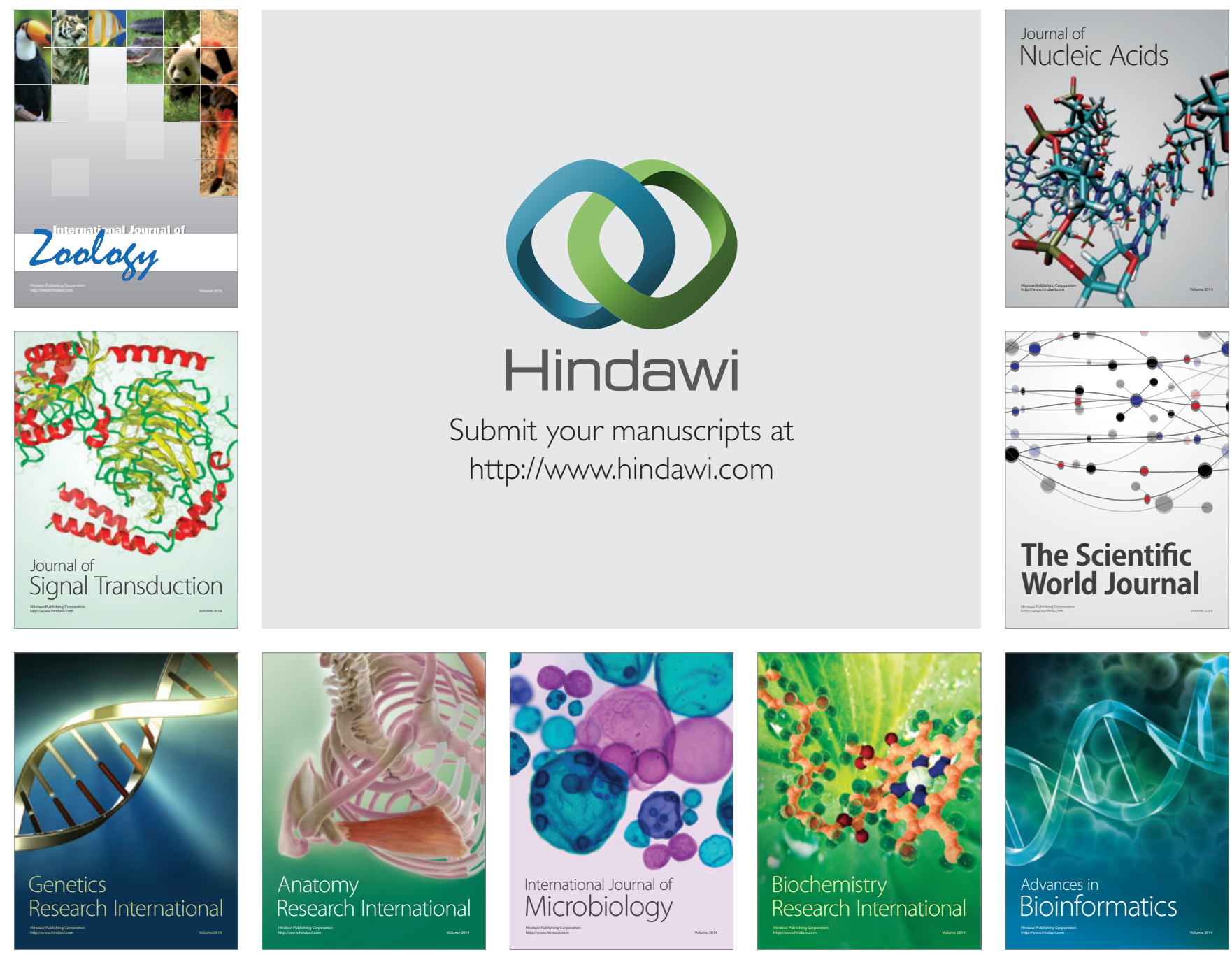

The Scientific World Journal
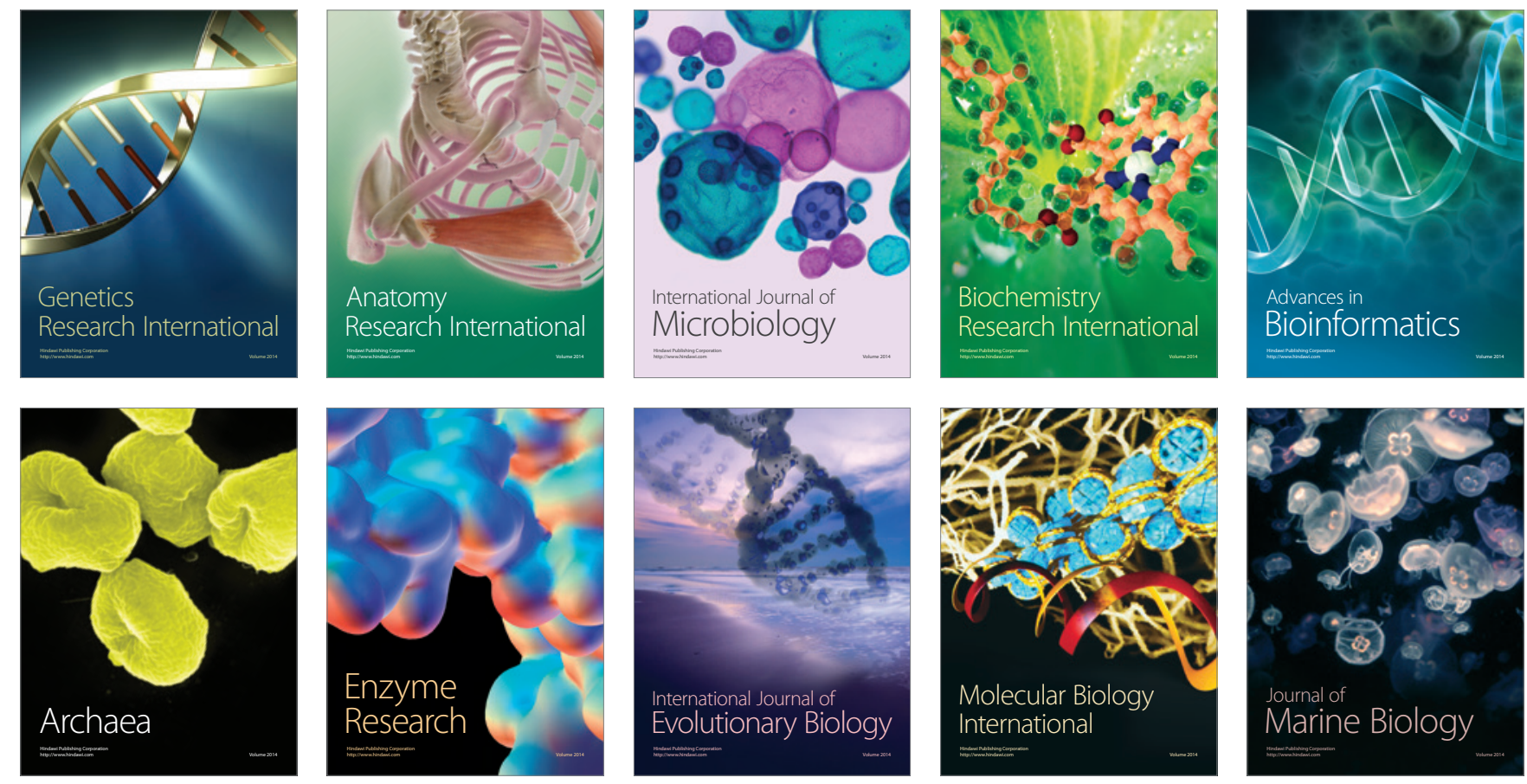